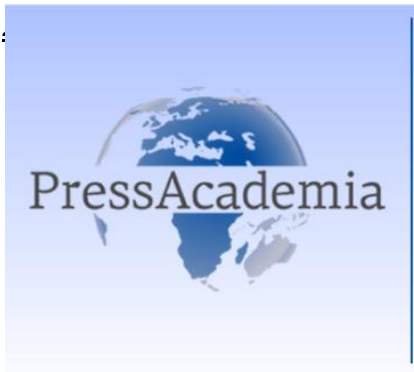

Press Academia Procedía

2nd World Conference on Technology, Innovation and Entrepreneurship

May 12-14, 2017, Istanbul, Turkey. Edited by Sefer Şener

\title{
AN INVESTIGATION OF AWARENESS LEVEL OF THE CONSTRUCTION EMPLOYEES ON OCCUPATIONAL SAFETY
}

\section{DOI: 10.17261/Pressacademia.2017.540 PAP-WCTIE-V.4-2017(32)-p.245-254}

\author{
Zafer Utlu ${ }^{1}$, Serenay Sahin ${ }^{2}$ \\ ${ }^{1}$ İstanbul Aydın University, zaferutlu@aydin.edu.tr \\ ${ }^{2}$ Omer Halisdemir University, İstanbul Aydın University, ssahin@ohu.edu.tr
}

\begin{abstract}
Occupational safety is an essential element in the prevention of occupational accidents, but more importantly, employees should be aware of the necessity of occupational safety and must avoid dangerous movements that can cause accidents. The safe behavior of employees can be considered as the most important factor in preventing occupational accidents, especially in the construction industry where work place accidents are very common. Working conditions in the construction sector have been changing because of rapid development of technology. Also, demand for different construction types has been increasing. The most difficult task is undertaken by workers to meet this increased demand. Working conditions have become inharmonious because of the need to meet the demand and the construction with the costumer and also the difference between the working areas. This situation brings about the employees are treated like machines and forced to work in hazardous areas. The most common reasons of accidents in this sector are mainly the various dangers arise from the structural features of the sector, lack of knowledge about the conditions of occupational health and safety, not to change the standard working style and the desire of employers to make more profit. The aim of occupational safety in this sector is to diminish the level of the workplace accidents and to make workers conscious of the issue consequently transforming their safety attitudes to a culture. The aim of this paper is to investigate the opinions of workers in construction areas on occupational health and safety. For this purpose, a questionnaire is conducted and applied in various construction sites in Niğde. The obtained results are thoroughly analyzed by SPSS 24 packet programme.
\end{abstract}

Keywords: Construction, occupational health, occupational safety, SPSS, survey JEL Codes: J28, 038, 123

\section{INTRODUCTION}

Fatal occupational accidents that have occurred in the construction sector in recent years have once again revealed how important and necessary work safety practices are in this area. With the increasing number of occupational accidents, people have started to think that the protective approaches against these accidents are either incomplete or wrong, or those approaches are not applied, or the people responsible for applying these approaches do not fully fulfill their duties. In spite of the existence of the legal regulations to prevent these accidents, the existence of written rules only is not sufficient for the perception, internalization, and enforcement of these rules by employees/employers / occupational health and safety professionals. In construction work, there is generally a protection approach known by everyone in terms of safety precaution, which is the belief that the use of personal protective equipment is sufficient. However, the aim of the work safety studies is to secure the workplace first and then to take precautions for the safety of employees if necessary. Even this misconception can be regarded as one of the most important reasons for the happening of occupational accidents. Construction workers and employers are not aware of the importance of security measures, so they consider these measures to be unnecessary, difficult to implement and causing material loss, and both parties struggle to keep working with their own truths by acting as illegitimately as possible. Employers often ignore the fact that their employees do not obey the rules that prevent occupational accidents. Even some of the employers do not consider it necessary to insure their 
employees. Researching and discovering the causes of occupational accidents and occupational diseases scientifically has the potential to virtually eliminate almost all of the occupational accidents. Prepared with this in mind, our survey was carried out with 50 employees working on various construction sites in Niğde under the heading "Occupational Health and Safety Research". In our survey, there are parts about employees' personal information (education, marital status, working hours, etc.), their knowledge about occupational accidents and occupational diseases, their experiences and opinions, and their knowledge about occupational safety in their workplaces. The aim of this study is to find out what employees working in construction sites think about occupational health and safety, how occupational safety is perceived among construction sector workers, whether employers fulfill their obligations related to occupational health and safety, and whether occupational safety is regarded necessary. The data obtained as a result of the survey was analyzed and interpreted by SPSS.

\section{GENERAL CHARACTERISTICS OF CONSTRUCTION SECTOR AND IMPORTANCE OF OCCUPATIONAL SAFETY IN THE SECTOR}

\subsection{General Characteristics of Construction Sector}

The construction sector is considered different from other sectors due to its characteristics and needs different applications. One of the distinguishing features of the construction sector is that each construction work is based on a project and each project is different from each other (Tüzer, 2012). The reasons why projects differ from each other is that the construction sites, the height of the building, the number of employees working and the equipment used differ from each other. Apart from that, the construction industry has other features that are different from other sectors: workers in this sector are unqualified, work experience of workers is low and the working methods they are accustomed to may be dangerous and because the construction industry needs seasonal workers, workers are hired on a temporary basis, therefore, the number of uninsured employees is high (Demirkesen \& Arditi, 2011). These are not the only features that distinguish the construction sector from other sectors; the frequency of fatal occupational accidents in the sector causes this sector to be under the spotlight. These features and differences, which the construction sector has, have made the sector to be more focus of interest than other sectors. Basically, we can list the features that distinguish the construction sector from other sectors except for the ones we have already mentioned as follows (Güner, 2004; Yılmaz, 2009; Sandaloğlu, 2014):

1. Constructions are temporary works and working periods are pre-determined.

2. Employees are likely to be employed/fired on a continuous basis.

3. Unqualified employees are employed.

4. Working places are often far from employees' families.

5. The production type and the diversity of materials used to cause the rules of occupational safety to be applied to vary.

6. In the construction sector, the production site is temporary while the product is permanent.

7. Working in building sites is hard and dangerous.

8. Branching out in the construction industry is quite high and each branch has its own risks.

9. Since human relationships last only until the end of the project period, relationships between people do not usually continue after the project.

10. In the construction sector, subcontractors are used in almost every business, including large firms.

11. No matter how advanced the technology is, the more labor-intensive production is preferred, which causes the jobs to not finish in time and to be of poor quality.

\subsection{Causes of Occupational Accidents in the Construction Sector}

Occupational safety is the work done to prevent employees from suffering physical/ mental and psychological damage due to their working environment, the work equipment they use and the work they do. Occupational safety has taken its place both in legislations and in practice as compulsory in every workplace and sector regardless of hazard level. But the most important reason why occupational safety attracts so much attention in the construction industry is work accidents and deaths as a result of job insecurity. Each project is different, but the work is fundamentally similar and flightiness of occupational safety officers and employees' working under their own rules cause errors to be ignored, unregistered work, even job accidents being regarded as normal deaths. Perhaps one of the factors that have an important role in the occupational accidents is trying to provide job security with the information that is not available in the working area. In 
addition to the ones mentioned above, the causes of occupational accidents in the construction sector can be summarized as follows (Tüzer, 2012; Güner, 2004; Yılmaz, 2009; Sandaloğlu, 2014; Okatan \& Yüzbaşıgil, 2011):

1. Pressure of finishing the jobs as quickly and low- cost as possible,

2. Failure to ensure cooperation in the workplace due to the fact that most of the jobs are provided by subcontractors,

3. Working unconsciously,

4. Long working hours and environmental-ecological impact,

5. Absence/inadequacy of employees' occupational safety training and on-the-job training,

6. The low rate of unionization and the difficulty of acquiring the working rights,

7. Employees doing jobs outside their areas of responsibility,

8. Misusing or not using work equipment,

9. Regarding it unnecessary to comply with the rules of safety and fatalism,

10. Incautious and careless working due to low fees,

11. Lack/inadequacy of necessary supervision in work fields,

12. Insecurity of work places,

13. Occupational safety professionals do not work independent from the employers and therefore can not play an active role in correcting the insecurities.

\subsection{Occupational Safety in Construction Sector}

The construction sector can be regarded as a sector open to occupational accidents due to working at height, exterior painting and siding, scaffolding and dismantling, construction of electrical installations. However, the fact that this sector is open to occupational accidents does not mean that the accidents will always occur and cannot be prevented. Unfortunately, when you speak of occupational safety in our country, the only thing that comes to our mind is wearing personal protective equipment (PPE), i.e. helmets, safety belts. However, occupational safety requires taking precautions at workplace rather than taking precautions on the worker. The use of personal protective equipment does not prevent the accident from happening but only helps to reduce the effect of the accident on the individual. Instead, collective protection measures should be preferred and only in this way it may be possible to prevent occupational accidents. It is also accepted by employers to take precautions on employees, therefore they do not want to bear the cost of purchasing protective equipment, and therefore accept job security as a cost-enhancing factor. However, the fact that the workplace is safe reduces the cost of the employer, leads to higher quality work, and even increases profitability.

The preparation of the health and safety plan while in the project phase and the active implementation of security measures will ensure that all workers in the construction site are protected from occupational accidents (Karaman, Çivici, Kale, 2011). If the plan is not implemented and remains on the paper, it will not be possible to prevent work accidents in construction works. Regulation on Occupational Health and Safety in Construction Works, which is in force in our country, obliged the workplaces to prepare "Health and Safety Plan" in construction works. The aim is to prevent work accidents. However, as seen from the work accidents, the plans are either not prepared or not paid adequate importance to or not applied even if they have been prepared.

The people who undertake tasks from start to finish of the project are in fact responsible for the provision of work safety. In order to prevent work accidents in the construction sector, the civil engineer must specify in detail the nature of the materials, the durability of the structures, what the workers will do, what kind of work will be used on the site and which equipment will be used. For this reason, the fact that engineers can become experts, especially the fact that civil engineers have this right, is promising in preventing job accidents and occupational diseases. The one who does a job best is the one who knows that job best, so, construction engineers are really needed to prevent accidents in the construction sector.

In order to prevent work accidents in work areas, and ensure the health and life safety of employees and the people around the construction sites, the following practices must be strictly applied in accordance with the legislations. These are:

1. Health and safety signs inside and outside the construction sites must definitely be used.

2. The construction site must be kept under constant supervision and nonconformities must be eliminated immediately, 
3. Employees should be trained within certain periods of time before and after starting work,

4. The distribution of tasks among the employees should be clearly defined and nobody should do any other work outside this responsibility,

5. Personal protective equipment must be suitably used, clean, maintained, and must not be left at random places,

6. Workplaces must be designed in accordance with weather conditions and employees must not be affected by external conditions for any reason,

7. Equipment, pointed tools, unshielded machines, hand tools, parapets used in works at height, floor openings must not be used until they are safe.

8. Occupational safety experts and other occupational health and safety officers must be professionally trained, must take the necessary precautions and must not hesitate to contact the relevant departments in case,

9. Field inspections must be carried out on a daily basis, incorrect working methods must be determined and if necessary, each worker must be told how to do the job correctly.

\section{CONSTRUCTION SECTOR EMPLOYEES' PERSPECTIVES AND ATTITUDES ON OCCUPATIONAL SAFETY}

A survey found that the construction industry was at risk of $51,9496 \%$ in terms of occupational safety. It is clear from this result that the construction works have a dangerous structure that can cause work accidents and occupational diseases (Kuruoğlu, Kuruoğlu, Akyıldız, 2007). Employees working in the construction sector are generally considered to have low qualifications, to not obey rules, and believe in fatalism. For this reason, no matter what precautions are taken in the construction sites, occupational accidents cannot be prevented because of dangerous movements of employees. Apart from this, those who have dedicated their years to working in this area can also argue that they know best how to do their work and they do not need to be taught about their works. Have these thoughts changed after fatal work accidents happening so frequently today? Do employers/ specialists or other relevant persons/ units ignore the occupational safety precautions due to their cost while employees demand life security? The answers to these questions will reveal important information about work accidents. We should also try to find answers for these two questions: Do employees lose their lives because they are not well informed about their legal rights? Does everyone fulfill their responsibilities to change the dangerous working habits that have come up to day-to-day? The survey was conducted within this scope and the results were as follows. With the survey we conducted in the construction sector, we searched for employees' answers and tried to find out whether the employees cared and knew about occupational safety. The data obtained as a result of the survey was analyzed by the SPSS program under the heading of findings.

\section{FINDINGS}

\subsection{Reliability Analysis}

This analysis aims to demonstrate the consistency between the answers given to the survey and the answers to the other questions. This situation makes it clear that those who took the survey actually cared about it. In the reliability analysis, the alpha $(\alpha)$ coefficient is mostly used and a range for this value is predicted. When we look at the reliability analysis of our survey, it is seen that $\alpha$ is 0,80 in Table 1 , which shows that the survey is very reliable.

Table 1: Reliability Analysis

\begin{tabular}{cc}
\hline Alpha Coefficient & $\begin{array}{c}\text { Total Number of } \\
\text { Answered Value } \\
0,801\end{array}$ \\
& 35 \\
\hline
\end{tabular}

\subsection{Frequency Analysis}

This analysis demonstrates a brief summary of the data and reveals the number of responses given to the variables. With this analysis, we are able to interpret our survey results in a general way. The results obtained from the frequency analysis are as follows:

Table 2: Educational Status 


\begin{tabular}{|llcccc|}
\hline \multirow{5}{*}{ Valid } & Frequency & Percentage (\%) & $\begin{array}{c}\text { Valid Percentage } \\
\text { (\%) }\end{array}$ & $\begin{array}{c}\text { Cumulative } \\
\text { Percentage (\%) }\end{array}$ \\
\cline { 2 - 6 } & Primary School & 11 & 22,0 & 22,0 & 22,0 \\
\cline { 2 - 6 } & Secondary School & 15 & 30,0 & 30,0 & 52,0 \\
\cline { 2 - 6 } & High School & 13 & 26,0 & 26,0 & 78,0 \\
\cline { 2 - 6 } & $\begin{array}{l}\text { Vocational High } \\
\text { School }\end{array}$ & 5 & 10,0 & 10,0 & 88,0 \\
\cline { 2 - 6 } & University & 5 & 10,0 & 10,0 & 100,0 \\
\hline & Junior college & 1 & 2,0 & 2,0 & 98,0 \\
\cline { 2 - 6 } & Total & 50 & 100,0 & 100,0 & \\
\hline
\end{tabular}

The first variable is determined as educational status. When we look at the frequency values obtained as a result of the survey, we can see under the frequency column that 11 primary school graduates, 15 secondary school graduates, 13 high school graduates, 5 vocational high school graduates, 5 university graduates and 1 junior college graduates participated in the survey. Another variable is whether they have had a work accident up till then. When this variable was analyzed, the values in Table 3 were obtained.

Table 3: Have You Had a Work Accident Before?

\begin{tabular}{|cccccc|}
\hline \multirow{3}{*}{ Valid } & & Frequency & Percentage (\%) & $\begin{array}{c}\text { Valid Percentage } \\
\text { (\%) }\end{array}$ & $\begin{array}{c}\text { Cumulative } \\
\text { Percentage (\%) }\end{array}$ \\
\cline { 2 - 6 } & Yes & 11 & 22,0 & 22,0 & 22,0 \\
\cline { 2 - 6 } & No & 39 & 78,0 & 78,0 & 100,0 \\
\cline { 2 - 6 } & Total & 50 & 100,0 & 100,0 & - \\
\hline
\end{tabular}

The data obtained shows that 11 out of 50 respondents had a work accident before and 39 did not have a work accident before. This means $22 \%$ of them have had work accidents. In the analysis of the variable indicating whether employees caught an occupational disease, it has been found out that a smaller proportion of employees caught occupational diseases.

Table 4: Do You Have an Occupational Disease?

\begin{tabular}{|c|c|c|c|c|c|}
\hline & & Frequency & Percentage (\%) & $\begin{array}{c}\text { Valid Percentage } \\
(\%)\end{array}$ & $\begin{array}{c}\text { Cumulative } \\
\text { Percentage (\%) } \\
\end{array}$ \\
\hline \multirow{3}{*}{ Valid } & Yes & 2 & 4,0 & 4,0 & 4,0 \\
\hline & No & 48 & 96,0 & 96,0 & 100,0 \\
\hline & Total & 50 & 100,0 & 100,0 & - \\
\hline
\end{tabular}

As seen in the table above, only 2 out of 50 participants state that they caught an occupational disease. When Table 3 and Table 4 are interpreted, it is understood that the incidence of occupational accidents is more frequent than that of occupational diseases, or that although employees caught occupational diseases, they did not mention it. Today, employees are obliged to receive occupational health and safety training (Law no. 6331, Article 17). This not only plays an active role in preventing work accidents but also raises awareness of employees and removes any losses. In this context, when we asked the participants whether or not they have received occupational health and safety training in their workplaces, the results in Table 5 were obtained:

Table 5: Have You Received any Training on Occupational Health and Safety?

\begin{tabular}{|cccccc|}
\hline \multirow{3}{*}{ Valid } & & Frequency & Percentage (\%) & $\begin{array}{c}\text { Valid Percentage } \\
\text { (\%) }\end{array}$ & $\begin{array}{c}\text { Cumulative } \\
\text { Percentage (\%) }\end{array}$ \\
\cline { 2 - 6 } & Yes & 33 & 66,0 & 66,0 & 66,0 \\
\cline { 2 - 6 } & No & 17 & 34,0 & 34,0 & 100,0 \\
\cline { 2 - 6 } & Total & 50 & 100,0 & 100,0 & - \\
\hline
\end{tabular}

33 of 50 employees stated that they had received occupational health and safety training while 17 stated that they had not received occupational health and safety training. This poses a serious problem for the construction industry, which is 
among hazardous sectors. When we asked the construction workers whether they were aware of the personal protective equipment provided in the area of occupational health and safety to prevent them from being affected by the hazards or to minimize this risk (Table 6), 13 people said they had no information about personal protective equipment (PPE).

Table 6: Do you know what personal protective equipment is?

\begin{tabular}{|c|c|c|c|c|c|}
\hline & & Frequency & Percentage (\%) & $\begin{array}{c}\text { Valid Percentage } \\
(\%)\end{array}$ & $\begin{array}{c}\text { Cumulative } \\
\text { Percentage (\%) }\end{array}$ \\
\hline \multirow{3}{*}{ Valid } & Yes & 37 & 74,0 & 74,0 & 74,0 \\
\hline & No & 13 & 26,0 & 26,0 & 100,0 \\
\hline & Total & 50 & 100,0 & 100,0 & - \\
\hline
\end{tabular}

Thirty-seven people, however, stated that they knew what personal protective equipment is. As a result of this analysis, it can be seen how important it is to inform employees through occupational health and safety trainings.

Table 7: Do You Have any Suggestions or Complaints About Occupational Health and Safety?

\begin{tabular}{|c|c|c|c|c|c|}
\hline & & Frequency & Percentage (\%) & $\begin{array}{c}\text { Valid Percentage } \\
\text { (\%) }\end{array}$ & $\begin{array}{c}\text { Cumulative } \\
\text { Percentage (\%) }\end{array}$ \\
\hline \multirow{3}{*}{ Valid } & Yes & 22 & 44,0 & 44,0 & 44,0 \\
\hline & No & 28 & 56,0 & 56,0 & 100,0 \\
\hline & Total & 50 & 100,0 & 100,0 & - \\
\hline
\end{tabular}

Employees are generally assumed to have no expectations of work health and safety. However, we see in the table above that 22 out of 50 people, i.e. $44 \%$ of respondents, indicated that they had suggestions or complaints about occupational health and safety. In this case, it is not possible to say that the employees are indifferent to the measures taken or not taken. There are occupational safety specialists and occupational physicians who are involved in providing occupational health and safety at workplaces. It is important for employees to have a dialogue with the expert and the workplace physician and to be able to access them easily. In the case of any problems, employees should have the right to remedy this problem by informing the officers. We can see that 29 employees responded negatively (Table 8 ) to the question "Do you know the name of your occupational safety specialist and occupational physician in your workplace?" This means $58 \%$ of employees do not know whom they can reach when there is a problem.

Table 8: Do You Know The Name of Your Occupational Safety Specialist and Occupational Physician in Your Workplace?

\begin{tabular}{|cccccc|}
\hline \multirow{3}{*}{ Valid } & & Frequency & Percentage (\%) & $\begin{array}{c}\text { Valid Percentage } \\
\text { (\%) }\end{array}$ & $\begin{array}{c}\text { Cumulative } \\
\text { Percentage (\%) }\end{array}$ \\
\cline { 2 - 6 } & Yes & 21 & 42,0 & 42,0 & 42,0 \\
\cline { 2 - 6 } & No & 29 & 58,0 & 58,0 & 100,0 \\
\cline { 2 - 6 } & Total & 50 & 100,0 & 100,0 & - \\
\hline
\end{tabular}

On the other hand, 23 respondents answered yes while 27 (54\%) respondents (Table 9) responded that the measures were not adequate to the question "Are the health and safety precautions in your workplace adequate?"

Table 9: Are the Health and Safety Precautions In Your Workplace Adequate?

\begin{tabular}{|c|c|c|c|c|c|}
\hline & & Frequency & Percentage (\%) & $\begin{array}{c}\text { Valid Percentage } \\
(\%)\end{array}$ & $\begin{array}{c}\text { Cumulative } \\
\text { Percentage (\%) }\end{array}$ \\
\hline & Yes & 23 & 46,0 & 46,0 & 46,0 \\
\hline \multirow[t]{2}{*}{ Valid } & No & 27 & 54,0 & 54,0 & 100,0 \\
\hline & Total & 50 & 100,0 & 100,0 & - \\
\hline
\end{tabular}

In Table 10, we can see a result that is contrary to the general opinion that "employees do not care about occupational safety; they do not care about themselves". It can be seen that all 50 employees who participated in the survey are aware of the importance of occupational safety.

Table 10: Do You Think Occupational Safety Is Important? 


\begin{tabular}{|cccccc|}
\hline & & Frequency & Percentage (\%) & $\begin{array}{c}\text { Valid Percentage } \\
(\%)\end{array}$ & $\begin{array}{c}\text { Cumulative } \\
\text { Percentage (\%) }\end{array}$ \\
\cline { 2 - 5 } Valid & Yes & 50 & 100,0 & 100,0 & 100,0 \\
\hline
\end{tabular}

Our latest variable is about fate, a notion that is quite unsuitable for occupational health and safety, but still has many supporters. When we asked employees participating in the survey whether it was fate to have an occupational accident, the data in Table 11 appeared.

Table 11: Do You Think It Is Fate To Have An Occupational Accident or Catch an Occupational Disease?

\begin{tabular}{|cccccc|}
\hline \multirow{7}{*}{ Valid } & Frequency & Percentage (\%) & $\begin{array}{c}\text { Valid Percentage } \\
\text { (\%) }\end{array}$ & $\begin{array}{c}\text { Cumulative } \\
\text { Percentage (\%) }\end{array}$ \\
\cline { 2 - 6 } & Yes & 19 & 38,0 & 38,8 & 38,8 \\
\cline { 2 - 6 } & No & 30 & 60,0 & 61,2 & 100,0 \\
\cline { 2 - 6 } & Total & 49 & 98,0 & 100,0 & - \\
\cline { 2 - 6 } & & 1 & 2,0 & - & - \\
\hline
\end{tabular}

Of the 50 respondents, 49 responded to this question and 19 said yes while 30 said that occupational accident was not fate. When we evaluate the results, we can see that employees are not indifferent to occupational health and safety and that they are aware of the fact that health and safety precautions are important. However, another problem we realized while applying the survey was that employees were afraid of asking the employer for something or telling the employer about their problems, which indicated that health and safety precautions are both incomplete and that no work was being done to complete it. Before responding negatively to the survey questions about workplace accidents, training or safety, the employees were anxious asking "Will the employer know about our answers?" or they were worried that they could lose their jobs if their employer knew about their answers.

\subsection{Chi Square (Independence) Test}

The chi-square test is based on whether the difference between observed frequencies (G) and expected frequencies (B) is statistically significant. The chi-square distribution is usually used to test two independent qualitative criteria. The zero hypothesis $\left(\mathrm{H}_{0}\right)$ indicates that two criteria are independent and the research hypothesis $\left(\mathrm{H}_{1}\right)$ indicates that there is a relationship between two criteria (Güngör, Bulut, 2008). We will try to reveal the relation between some of the data obtained from the survey with Chi-square test. First we will check whether there is a relationship between occupational health and safety practices applied at workplaces and the wages paid to employees.

Our hypotheses are as follows:

$\mathrm{H}_{0}$ : There is no significant relationship between wages paid to employees and occupational health and safety practices applied at workplaces.

$\mathrm{H}_{1}$ : There is a significant relationship between wages paid to employees and occupational health and safety practices applied at workplaces.

Table 12: Wages Paid To Employees*Occupational Health and Safety Practices Applied at Workplaces Chi-Square Test

\begin{tabular}{|lccc|}
\hline & Value & $\begin{array}{c}\text { Degree of } \\
\text { Freedom }\end{array}$ & P Value \\
\hline Pearson Chi Square Value & 9,742 & 1 &, 002 \\
\hline $\begin{array}{l}\text { Correction Applied Chi } \\
\text { Square Value }\end{array}$ & 8,052 & 1 &, 005 \\
\hline $\begin{array}{l}\text { Number of respondents } \\
\text { giving valid responses }\end{array}$ & 50 & & \\
\hline
\end{tabular}

a. 0 cell $(0.0 \%)$ is smaller than the expected value of 5 . 
According to the analysis results above, the Pearson Chi-Square value appears readable in the Chi Square test. That is because $20 \%$ of the cells in the item a below the table are smaller than 5 and our value is concluded as $0 \%$. When evaluating this data, $\mathrm{H}_{0}$ is rejected and $\mathrm{H}_{1}$ is verified since the Pearson value $(, 002)$ is smaller than 0.05 . This implies that there is a significant relationship between the wages paid to the employees and the occupational health and safety practices applied in the workplace. Another hypothesis has been set up between health and safety precautions at the workplace and employees' regarding occupational accidents or diseases as fate.

Our hypotheses about it are as follows:

$\mathrm{H}_{0}$ : There is no significant relationship between the adequacy of the health and safety precautions at the workplace and employees' regarding occupational accidents or diseases as fate.

$\mathrm{H}_{1}$ : There is a significant relationship between the adequacy of the health and safety precautions at the workplace and employees' regarding occupational accidents or diseases as fate.

According to the analysis results in Table 13, the Pearson Chi-Square value appears readable in the Chi-square test. That is because $20 \%$ of the cells in the item a below the table are smaller than 5 and our value is concluded as $0 \%$. When evaluating this data, $\mathrm{H}_{1}$ is rejected and $\mathrm{H}_{0}$ is verified since the Pearson value $(, 754)$ is greater than 0.05 . This means there is no significant relationship between the adequacy of the health and safety precautions at the workplace and employees' regarding occupational accidents or diseases as fate.

Table 13: The Adequacy of the Health and Safety Precautions at the Workplace * Employees' Regarding Occupational Accidents or Diseases as Fate Chi-Square Test

\begin{tabular}{|cccc|}
\hline & Value & $\begin{array}{c}\text { Degree of } \\
\text { Freedom }\end{array}$ & P Value \\
\hline $\begin{array}{c}\text { Pearson Chi Square } \\
\text { Value }\end{array}$ &, $098^{\mathrm{a}}$ & 1 &, 754 \\
\hline $\begin{array}{c}\text { Correction Applied } \\
\text { Chi Square Value }\end{array}$ &, 000 & 1 & \\
\hline $\begin{array}{c}\text { Number of } \\
\text { respondents giving } \\
\text { valid responses }\end{array}$ & 49 & & \\
\hline
\end{tabular}

a. 0 cell $(0.0 \%)$ is smaller than the expected value of 5

The following results were obtained in the Chi-Square test conducted to find out whether there is a relationship between the adequacy of health and safety precautions at workplaces and whether or not employees have suggestions or complaints about occupational health and safety:

Table 14: The Adequacy of Health and Safety Precautions at Workplaces * Whether or not Employees Have Suggestions or Complaints about Occupational Health and Safety Chi-Square Test

\begin{tabular}{|cccc|}
\hline & Value & $\begin{array}{c}\text { Degree of } \\
\text { Freedom }\end{array}$ & P Value \\
\hline $\begin{array}{c}\text { Pearson Chi Square } \\
\text { Value }\end{array}$ & $12,239^{\mathrm{a}}$ & 1 &, 000 \\
\hline $\begin{array}{c}\text { Correction Applied } \\
\text { Chi Square Value }\end{array}$ & 10,321 & 1 &, 001 \\
\hline $\begin{array}{c}\text { Number of } \\
\text { respondents giving } \\
\text { valid responses }\end{array}$ & 50 & & \\
\hline
\end{tabular}

a. 0 cell $(0.0 \%)$ is smaller than the expected value of 5

According to the analysis results in Table 14, the Pearson Chi-Square value appears readable in the Chi-square test. That is because $20 \%$ of the cells in the item a below the table are smaller than 5 and our value is concluded as $0 \%$. When evaluating this data, $\mathrm{H}_{0}$ is rejected and $\mathrm{H}_{1}$ is verified since the Pearson value $(, 000)$ is smaller than 0,05 . This means there is a significant relationship between the adequacy of health and safety precautions at workplaces and whether or not employees have suggestions or complaints about occupational health and safety. 


\section{CONCLUSION}

It is seen in the analysis results that the prejudice that has always been accepted as true that the employees do not care about their own lives and do not obey the rules has proved wrong. If employers and other related people want to implement occupational health and safety precautions, they can easily include employees into these practices. Another analysis supporting this result shows that employees also have requests and complaints related to occupational health and safety which can be seen in the adequacy of the health and safety precautions taken at the workplaces. Another analysis shows that there is a significant relationship between wages paid to employees and occupational health and safety practices carried out at workplaces. This shows that employers pay attention to applying occupational health and safety in workplaces where wages are not seen as a cost. The most important and desired result is that occupational accidents are not regarded as fate. This analysis has shown that this perception may change over time. It can be argued that the concept of fate is just a pretext for not practicing occupational safety. Under the pretext of fate, persons avoid taking responsibility and even accept nonhuman working conditions. When employers actually fulfill all their responsibilities regarding occupational safety, employees will also act in a manner that is truly in accordance with these rules. However, first of all, it is necessary for employers to convince their employees that they really attach importance to this issue. Thus, when there are no more occupational accidents, it will be seen that there is no such thing as an occupational accident.

The construction industry has its own unique working conditions and this sector is one of the most dangerous sectors, a sector in which hazards can be seen most and accidents and diseases can often be experienced. However, it will not be hard to prevent occupational accidents and occupational diseases with proper practices. In this context, one of the first things to do is to make everyone, not just occupational health and safety officers, accept the necessity and importance of occupational health and safety. For this reason, before telling the employees to obey these rules, it is important to explain to them why they should obey the rules. This means that we need to convince employees to comply with occupational health and safety regulations, and this can only happen with the security culture that will be provided in the workplaces. Another important issue is that those in charge of occupational health and safety do not have comprehensive knowledge of occupational safety or that they prefer not doing the right thing for some reasons. In this regard, a rewarding system can be used, in particular for both employees and occupational health and safety officers. The rewarding system provides motivation for employees, which increases the interest of people in this area and further reduces the rate of accidents. Occupational safety training is important in ensuring occupational health and safety. If employees are not trained on the job they are doing, they can cause occupational accidents with inappropriate behavior. It is known that employers and those who provide training in occupational health and safety do not pay attention to the training periods determined according to the provisions of the "Regulation on the Procedures and Principles of Occupational Health and Safety Trainings of Employees." It is also known that this training is apparently completed by giving only a written document. In this regard, the relevant ministry should conduct training by means of active audits; the ministry should even provide these training at workplaces with the competent staff if necessary. In addition to training, workplace periodic checks, periodic health checks, work accidents, near-miss reports, occupational diseases and risk assessment reports should be kept in the workplaces in an orderly manner, and most importantly, occupational health and safety practices should be shared not only among experts but also to all employees.

\section{REFERENCES}


Demirkesen, S.,Arditi,D. 2011, "Occupational Safety Training in Building Sector", Turkey Engineering News Journal, Volume: 469, 5, p. 4955.

Güner, A.F., Giritli, H. 2004, “Total Quality Management in Construction Industry and Implementations in Turkey", Journal of itü, Volume 3, 1, p. 19-30.

Güngör, M., Bulut,Y. 2008, “On The Chi-Square Test”, Journal of Eastern Anatolia Region Research,Volume 7, 1, p. 84-89.

Karaman, E., Çivici, T., Kale,S. 2011," Role and Importance of Occupational Health and Safety in the Construction Sector", 3. Occupational Health and Safety Symposium, Çanakkale.

Kuruoğlu, Y., Kuruoğlu, M.,Akyıldız, B. 2007, “Fiziksel Güce Dayalı Çalışan İnşaat İş̧ilerinin iş̧ Sağlığı ve Güvenliği Kapsamında Bulanık Mantıkla Risk Analizi", 4. Construction Management Congress, İstanbul.

Okatan, A., Yüzbaşıgil, R. 2011, "Accidents and Safety Precautions in the Construction Sector", 3. Occupational Health and Safety Symposium, Çanakkale.

Sandaloğlu, O. 2014, "The Evaluation Of The Construction Sector In Terms Of The Occupational Health And Safety", Graduation Project, Yeni Yüzyıl University Institute of Health Sciences.

Tüzer, F. 2012, "A Study On The Occupational Health And Safety In Construction Works In Istanbul”, Master's Thesis, İstanbul Kültür University Graduate School of Natural and Applied Sciences.

Yılmaz, D. 2009, "State Of Occupational Health And Safety And Environmental Management Systems In Istanbul Urban Transportation Construction Sites With Respect To Public Safety", Master's Thesis, Yıldız Teknik University Graduate School of Natural and Applied Sciences. 